\title{
Width-weight relationship and condition factor of $U$ cides cordatus (Crustacea, Decapoda, Ucididae) at tropical mangroves of Northeast Brazil
}

\author{
Marina S.L.C. Araújo ${ }^{1}$, Daniela S. Castiglioni ${ }^{2}$ \& Petrônio A. Coelho ${ }^{1,3^{\dagger}}$
}

1 Laboratório de Carcinologia, Museu de Oceanografia, Universidade Federal de Pernambuco (UFPE). Av. Arquitetura, s/n, Cidade Universitária, 50740-550 Recife, PE, Brazil. (mslc.araujo@gmail.com)
2 Departamento de Zootecnia e Ciências Biológicas, Centro Superior de Educação Norte do RS (CESNORS), Universidade Federal de Santa Maria (UFSM). Av. Independência, 3751,
Vista Alegre, 98300-000, Palmeira das Missões, RS, Brazil. (danielacastiglioni@yahoo.com.br)
3 Laboratório de Carcinologia, Universidade Federal de Alagoas (UFAL). Av. Divaldo Suruagy, s/n, Centro, 57200-000, Penedo, AL, Brazil.

\begin{abstract}
The present contribution aims at evaluating the carapace width $v$ s. humid weight relationship and the condition factor of $U$ cides cordatus (Linnaeus, 1763), in the mangrove forests of the Ariquindá and Mamucabas rivers, state of Pernambuco, Brazil. These two close areas present similar characteristics of vegetation and substrate, but exhibit different degrees of environmental conservation: the Ariquindá River is the preserved area, considered one of the last non-polluted of Pernambuco, while the Mamucabas River suffers impacts from damming, deforestation and deposition of waste. A total of 1,298 individuals of $U$. cordatus were collected. Males were larger and heavier than females, what is commonly observed in Brachyura. Ucides cordatus showed allometric negative growth $(p<0.05)$, which is probably related to the dilatation that this species develops in the lateral of the carapace, which stores six pairs of gills. The values of $b$ were within the limit established for aquatic organisms. Despite of the condition factor being considered an important feature to confirm the reproductive period, since it varies with cyclic activities, in the present study it was not correlated to the abundance of ovigerous females. However, it was considered a good parameter to evaluate environmental impacts, being significantly lower at the impacted area.
\end{abstract}

KEYWORDS. Allometric constant, carapace width, caranguejo-uçá, growth, humid weight.

RESUMO. Relação largura-peso e fator de condição de Ucides cordatus (Crustacea, Decapoda, Ucididae) em manguezais tropicais do Nordeste do Brasil. A presente contribuição visa avaliar a relação largura de carapaça vs. peso úmido e o fator de condição de Ucides cordatus (Linnaeus, 1763), nos manguezais dos rios Ariquindá e Mamucabas, Estado de Pernambuco, Brasil. Essas duas áreas próximas apresentam características similares de vegetação e substrato, mas exibem diferentes níveis de conservação ambiental: o rio Ariquindá é a área preservada, considerado um dos últimos rios não poluídos de Pernambuco, enquanto o rio Mamucabas sofre impactos de represamento, desmatamento e deposição de lixo. Um total de 1.298 indivíduos de U. cordatus foi coletado. Machos foram mais largos e mais pesados que as fêmeas, o que é comumente observado em Brachyura. Ucides cordatus mostrou crescimento alométrico negativo $(p<0.05)$, o que está provavelmente relacionado à dilatação que esta espécie desenvolve na lateral da carapaça, que abriga seis pares de brânquias. Os valores de $b$ estiveram dentro do limite estabelecido para organismos aquáticos. Apesar do fator de condição ser considerado um importante aspecto para confirmar o período reprodutivo, visto que varia com atividades cíclicas, no presente estudo ele não esteve correlacionado com a abundância de fêmeas ovígeras. Entretanto, foi considerado um bom parâmetro para avaliar impactos ambientais, sendo significativamente menor na área impactada.

PALAVRAS-CHAVE. Constante alométrica, largura de carapaça, caranguejo-uçá, crescimento, peso úmido.

The studies of relative growth in Crustacea enable the interconversion between variables and the detection of morphological changes that appear with sexual maturity (PinHeIro \& Fransozo, 1993). Among the studies of biometric relationships, the size vs. weight one has been used for many species, being better represented by the power function $\left(y=a x^{b}\right)$ (HuXLEY, 1950), the same typically used in allometric studies (LE Cren, 1951; Pinheiro \& Fiscarelli, 2009). The constant $a$ represents the condition factor and the coefficient $b$ means the allometric constant that expresses the analogy between the two variables, $y$ (dependent variable, the weight) and $x$ (independent variable, the size) (PInHEIRO $\&$ FiscARelLI, 2009).

The condition factor acts as a parameter of the general "well-being" of a given species, indicating its degree of adjustment to the environment, since it varies with seasonal changes in the environmental conditions (BRAGA et al., 1985). It's an easy and rapid manner to study the individuals of natural or in captivity populations (SANTOS, 1978), or in the estimates of the stand crop in bioecological studies (Lotrich, 1973). It is correlated to the reproductive period, parasitic infections and susceptibility to diseases, rates of feeding and growth, and may also vary seasonally and spatially (Le Cren, 1951; Pinheiro \& Fransozo, 1993; Froese, 2006). VAzzoler (1996) cites that the condition factor is an important indicator of the healthiness of an individual and its value reflects the recent feeding conditions and/ or spending of energy (fat) in cyclic activities, as the reproduction, as well as the behavioral aspects of a given species.

The size vs. weight relationship is important for the elaboration of plans for sustainable exploitation of species with socio-economical value (LE CREN, 1951; Froese, 2006), including brachyuran decapod crustaceans, since the knowledge of the growth rates is important to comprehend the life cycle of a given species, as well as to diagnose alterations due to environmental impacts, as pollution, deforestation or overexploitation, by comparing with populations subjected to few or none anthropic impacts (CASTIGLIONI et al., 2006). Many species of this taxon are commonly found in estuaries and mangrove forests, and they are very exploited in the Brazilian coast.

The crab fauna is the most remarkable of estuaries and mangrove forests, and the burrowing species enables the oxygenation and drainage of the soil (MACintosh, 
1988). Among those species, stands out the semiterrestrial mangrove crab Ucides cordatus (Linnaeus, 1763), in the American coast of the Atlantic Ocean. In Brazil, $U$. cordatus is popularly known as "caranguejo-uçá" or "caranguejo-verdadeiro" (true crab). The growth of $U$. cordatus was studied by Geraldes \& CALVENTI (1983), Ostrensky et al. (1995) and Diele \& Косн (2010a). These authors have concluded that this species has a slow growth, but according to field studies accomplished in Northeast Brazil, fast growth rate has also been reported (Botelho et al., 1999; Ivo \& Gesteira, 1999; Ivo et al., 1999; VASCONCELOS et al., 1999). It's known that time, place and environmental factors may influence the growth rates of brachyuran species (BAPTISTA-METRI et al., 2005). Such facts highlight the importance of performing more studies on growth, even if a given species has been studied in other regions.

The growth, considering the carapace width $v s$. humid weight, as well as the condition factor, are aspects not well studied of the biology of the true crab, standing out the paper published by PinHEIRO \& FisCARelli (2009), at Southeast Brazil. Studies on other topics of the life history of $U$. cordatus were accomplished, as HATTORI \& PINHEIRO (2003) (fertility), Dalabona \& Loyola E Silva (2005) (sexual maturity), Pinheiro \& HatTori (2006) (relative growth), NordHaus et al. (2009) (burrowing behavior), NorDi et al. (2009) (gathering techniques) and in the Northeast of Brazil, stands out those published by MотAAlves (1975) (reproduction), Alcantara-Filho (1978) (population ecology), BотеLно et al. (1999) (population ecology, growth), Ivo \& Gesteira (1999) (a review on many aspects of its fisheries and life cycle), VASCONCELOS et al. (1999) (population ecology and growth) and ARAúJO \& CALADO (2008) (population ecology and reproduction). At the Ariquindá and Mamucabas Rivers, state of Pernambuco, Brazil, Castiglioni \& Coelho (2011) and CAstiglioni et al. (2011) have studied reproductive aspects of this species. Due to the socio-economic importance of the given species, more studies on the growth and condition factor are needed, especially if considered its current status of overexploited species, according to Ministério do Meio Ambiente (2004).

Despite of the papers written by BотеLнo et al. (1999), Ivo et al. (1999), VASCONCELos et al. (1999) and ARAúJo \& CALADO (2008) show some information on the relationship carapace width (CW) vs. humid weight (HW) for Northeastern Brazilian mangroves, no detail is given to the condition factor. The present study aims at contributing to the biological knowledge of $U$. cordatus, through the following specific objectives: to describe the crab biometry (CW and HW), the growth for the relationship between these two variables, the condition factor and its correlation with the reproductive period, as well as to evaluate the sexual and seasonal variations, and to compare two areas with different degrees of conservation, the Ariquindá and Mamucabas Rivers, important estuaries of the state of Pernambuco, Northeast Brazil.

\section{MATERIAL AND METHODS}

Sampling areas. The samples of Ucides cordatus were accomplished in the mangrove forests of the Ariquindá $\left(8^{\circ} 46^{\prime} 43.69^{\prime \prime} \mathrm{S}\right.$ and $\left.35^{\circ} 06^{\prime} 25.87^{\prime \prime} \mathrm{W}\right)$ and Mamucabas River ( $8^{\circ} 41^{\prime} 28.48^{\prime \prime S}$ and $\left.35^{\circ} 06^{\prime} 09.32^{\prime \prime} \mathrm{W}\right)$, both located in the Municipality of Tamandaré, State of Pernambuco, Brazil. The region has a climate within the As' type of Köppen system, i.e. hot and humid, with mean temperatures that vary between 25 and 30 ${ }^{\circ} \mathrm{C}$, and mean rainfall around $2.000 \mathrm{~mm}$ (Moura \& Passavante, 1995). Besides, this area exhibits two well defined seasons according to the level of rainfall: dry (from September to December) and rainy (from January to July) (Moura \& Passavante, 1995). These two close areas present similar characteristics of vegetation and substrate, but exhibit different degrees of conservation, as follows.

The Ariquindá River is inserted in the Guadalupe APA (Area of Environmental Preservation), with an extension of $7 \mathrm{~km}$ and, together with its tributary, União River, composes the Formoso River basin ( $\mathrm{CPRH}$, 1999). It is considered one of the last non polluted rivers of the state of Pernambuco (GREGo et al., 2009). The chosen mangrove area of Ariquindá River is located near its confluence with Formoso River, at Carneiros Beach, and in the field expeditions it could be noticed a dominance of the plant species Rhizophora mangle L., followed by Laguncularia racemosa (L.) Gaertn. f. and Avicennia schaueriana Stapf and Leechman ex Moldenke, the last one less frequent. The substratum was visually characterized as muddy sand.

The Mamucabas River is located, almost completely, in the Municipality of Tamandaré. This river rises at the west of the Saltinho Biological Reserve, being dammed after entering in the Reserve, forming a reservoir that supplies Tamandaré. From the spring until the coastal plain it runs in the surrounding areas of the municipality, meeting the Ilhetas River and together they disembogue (CPRH, 2003). It is considered an impacted estuary due to the housing occupation in the surrounding areas (SANTOS et al., 2001), with great deposition of waste and deforestation. The sampling area is located near the mouth of these rivers, and in the field expeditions it could be noticed a dominance of the plant species $L$. racemosa, followed by $R$. mangle and, in less abundance, $A$. schaueriana. The substratum was also visually characterized as muddy sand.

Christofoletti et al. (2012) performed a field experiment to evaluate the feeding preferences of $U$. cordatus, and found that this species of crab shows no preference for species of trees, so probably in the present study the small difference observed in the composition of the mangrove does not affect significantly our results. Samplings. The crabs were monthly collected from April 2008 to March 2009, by a professional crabber who used his arm or a hook to reach into the burrow (PINHEIRO \& 
Fiscarelli, 2001; Diele et al., 2005; Araúuo \& Calado, 2008), in three $5 \mathrm{~m}^{2}$ plots in each mangrove. All the area was explored. These plots were located parallel to the river and $20 \mathrm{~m}$ distant from each other. Sampling was carried out during low tide around the full or new moon; since the forest is flooded only during spring high tides, the crabs can be caught more easily in the softened sediment at these times. After the samples, the crabs were kept in plastic bags and transported to laboratory in coolers.

Laboratory activities. The crabs were separated by sex, and from each one, the carapace width $(\mathrm{CW})$ was measured using a vernier caliper of $0.01 \mathrm{~mm}$ of precision. The $\mathrm{CW}$ was taken considering the widest dimension. The humid weight (HW) of each crab was obtained with an electronic balance of $0.01 \mathrm{~g}$ of precision. The ovigerous condition of females was also noted.

Statistical analysis. The minimum, mean $( \pm$ standard deviation) and maximum values of CW and HW were determined for each sex and estuary. The MannWhitney-Wilcoxon $U$ test was applied to compare the $\mathrm{CW}$ and HW between sexes and estuaries ( $\alpha=0.05$; ZAR, 1996).

The growth of $U$. cordatus was described for each sex and estuary through the potency equation $\mathrm{HW}=a \mathrm{CW}^{b}$, where $\mathrm{HW}$ is the humid weight, $\mathrm{CW}$ is the carapace width, $b$ is the slope, and $a$ is the intercept. The fit was evaluated by the coefficient of determination $\left(\mathrm{r}^{2}\right)$. An Analysis of Covariance (ANCOVA) was used to compare the slopes and intercepts of the lines between sexes, to verify the possibility of grouping males and females by the same equation ( $\alpha=0.05$; ZAR, 1996). The type of weight increase was defined by the coefficient $b$ (isometric, $b=3$; positively allometric, $b>3$; and negatively allometric, $b<3$ ), which had its significance tested by the Student $t$ test ( $\alpha=0.05$; ZAR, 1996).

The condition factor (CF) was calculated by the formula $a=\mathrm{HW} / \mathrm{CW}^{b}$ (Le Cren, 1951). This formula was applied by each estuary and by seasons (Summer $=$ January to March; Autumn $=$ April to June; Winter $=$ July to September; and Spring = October to December) for each sex. The minimum, mean ( \pm standard deviation) and maximum values of the $\mathrm{CF}$ were estimated for each sex. The Mann-Whitney-Wilcoxon $U$ test was applied to compare the CF between sexes and estuaries, and the Kruskal-Wallis test, to compare the CF among seasons, followed by Dunn's a posteriori test when significant differences were detected ( $\alpha=0.05$; ZAR, 1996).

To verify the effectiveness of the $\mathrm{CF}$ as a determinant of the reproductive period (the period when the females incubate their eggs), the Pearson's linear coefficient (r) was applied to correlate the $\mathrm{CF}$ and the number of ovigerous females by seasons of the year $\left(\alpha=0.05 ; Z_{A R}, 1996\right)$. The values of $r$ vary from -1 to +1 and the nearest to these values, the strongest is the association between the examined variables. The zero score of this coefficient indicates the absence of correlation (AYres et al., 2007).

\section{RESULTS}

A total of 1,298 individuals of $U$. cordatus were collected. In both estuaries (Ariquindá and Mamucabas), male crabs showed larger CW and HW $(p<0.05)$ than females (Tab. I). At the Ariquindá River, males were $6.58 \mathrm{~mm}$ larger and $19.88 \mathrm{~g}$ heavier than females; at the Mamucabas River, males were $5.95 \mathrm{~mm}$ larger and 18.12 $\mathrm{g}$ heavier than females. Comparing both populations, no difference was observed in the size or weight $(p>0.05)$.

The species $U$. cordatus showed allometric negative growth $(p<0.05)$, tending to isometry, in both estuaries and sexes (Figs 1-4).

Regarding the sexual variations of the $\mathrm{CF}$, there was no statistically significant difference between sexes at Ariquindá River $(p>0.05)$, while at Mamucabas River, the CF was significantly higher in females than in males $(p<0.05)$. Regarding the spatial variations, the $\mathrm{CF}$ of males and females varied significantly between estuaries $(p<0.05)$, both being higher at the Ariquindá River (Tab. I). Regarding the seasonal variations, there was significant differences $(p<0.05)$, with the lowest values of the $\mathrm{CF}$ occurring in the winter, for both sexes and estuaries (Tab. II).

The number of ovigerous females by seasons of the year is presented in Tab. III. At Ariquindá River, they represent $13.09 \%$ of all captured females, and at Mamucabas River, $10.44 \%$. They were only found in the summer and in the autumn, and the most expressive number was found in the summer. Their abundance and the CF weren't correlated, both in the Ariquindá $(\mathrm{r}=0.34 ; \mathrm{t}=0.51)$ and in the Mamucabas Rivers $(r=0.06 ; \mathrm{t}=0.08)(p>0.05)$.

Tab. I. Minimum, mean ( \pm standard deviation) and maximum values of carapace width $(\mathrm{CW}, \mathrm{mm})$, humid weight $(\mathrm{HW}$, g) and condition factor $\left(\mathrm{CF}, 10^{-4}\right)$ of Ucides cordatus males and females sampled at the Ariquindá and Mamucabas Rivers estuaries, Northeast Brazil (N, number of individuals; Min, minimum; Max, maximum).

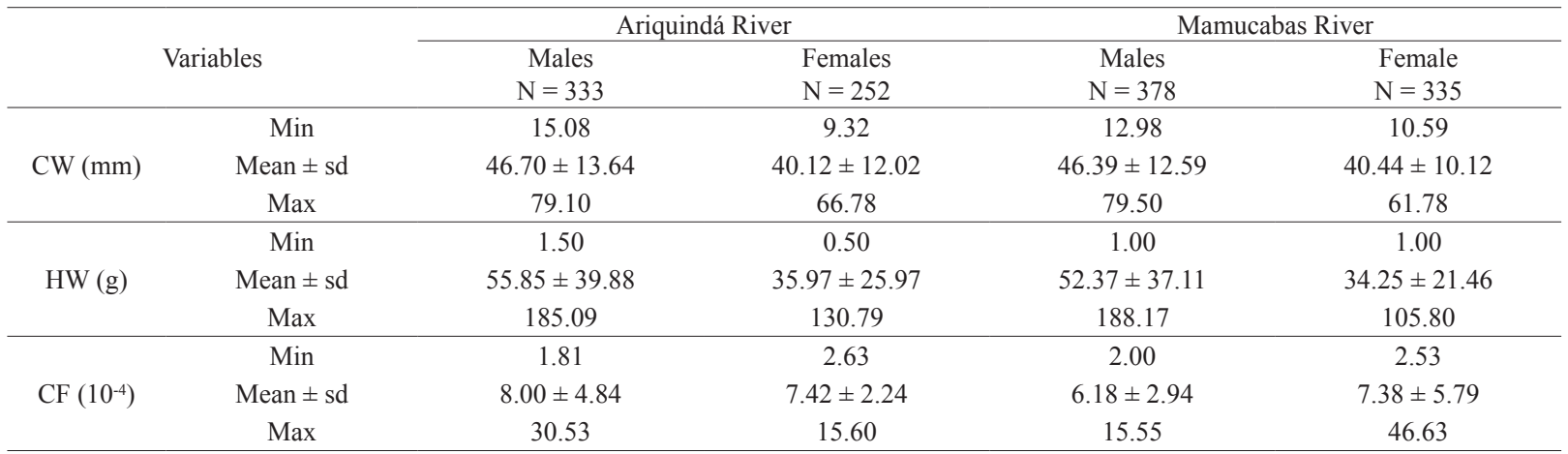



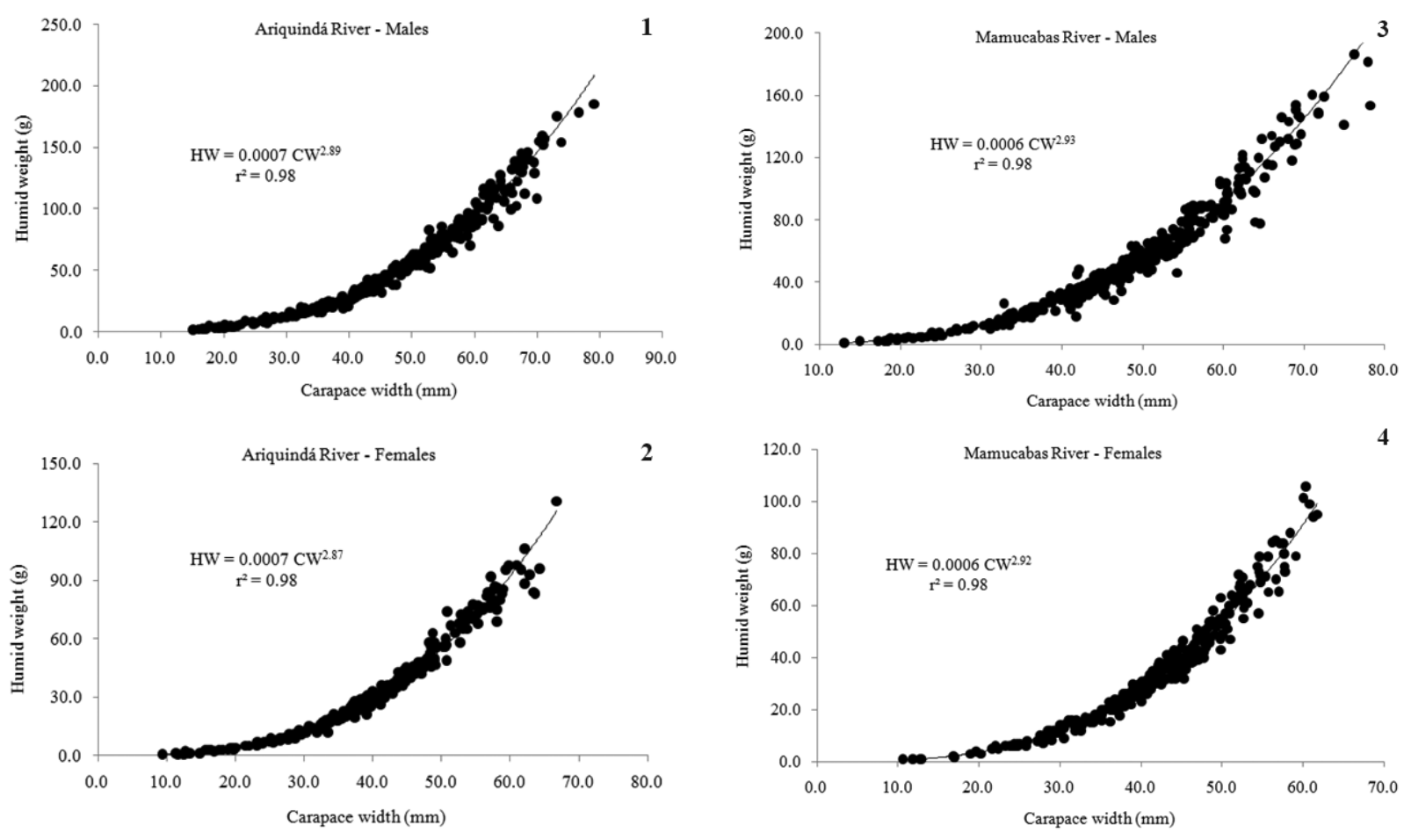

Figs 1, 2. Regression between the carapace width $(\mathrm{CW})$ and humid weight (HW) for Ucides cordatus males (1) and females (2) at the

Figs 3, 4. Regression between the carapace width $(\mathrm{CW})$ and humid weight (HW) for Ucides cordatus males (3) and females (4) at the Mamucabas River estuary, Northeast Brazil.

Tab. II. Power equations of the relationship between the carapace width (CW) vs. humid weight (HW) of Ucides cordatus males and females sampled in four different seasons at the Ariquindá and Mamucabas Rivers estuaries, Northeast Brazil. ${ }^{(1)}$ For the same sex and river, the same letter indicates that the condition factor did not differ significantly among seasons $(p<0.05)$. Condition factor in scientific notation $\left(10^{-4}\right)$.

\begin{tabular}{ccccc}
\hline \multirow{2}{*}{ Seasons } & \multicolumn{2}{c}{ Ariquindá River } & \multicolumn{2}{c}{ Mamucabas River } \\
& Males & Females & Males & Females \\
\hline Autumn & $\mathrm{HW}=11.60 \mathrm{CW}^{2.87} \mathrm{a}$ & $\mathrm{HW}=7.55 \mathrm{CW}^{2.86} \mathrm{a}$ & $\mathrm{HW}=5.36 \mathrm{CW}^{2.96} \mathrm{a}$ & $\mathrm{HW}=9.09 \mathrm{CW}^{2.82} \mathrm{a}$ \\
Winter & $\mathrm{HW}=4.14 \mathrm{CW}^{2.99} \mathrm{~b}$ & $\mathrm{HW}=6.32 \mathrm{CW}^{2.92} \mathrm{a}$ & $\mathrm{HW}=3.09 \mathrm{CW}^{3.03} \mathrm{~b}$ & $\mathrm{HW}=4.26 \mathrm{CW}^{2.97} \mathrm{~b}$ \\
Spring & $\mathrm{HW}=6.85 \mathrm{CW}^{2.88} \mathrm{c}$ & $\mathrm{HW}=7.01 \mathrm{CW}^{2.86} \mathrm{a}$ & $\mathrm{HW}=8.65 \mathrm{CW}^{2.84} \mathrm{c}$ & $\mathrm{HW}=8.09 \mathrm{CW}^{2.83} \mathrm{ab}$ \\
Summer & $\mathrm{HW}=7.11 \mathrm{CW}^{2.91} \mathrm{ac}$ & $\mathrm{HW}=9.53 \mathrm{CW}^{2.83} \mathrm{~b}$ & $\mathrm{HW}=6.12 \mathrm{CW}^{2.92} \mathrm{a}$ & $\mathrm{HW}=4.64 \mathrm{CW}^{2.97} \mathrm{~b}$ \\
\hline
\end{tabular}

Tab. III. Number of ovigerous females of Ucides cordatus sampled in four different seasons at the Ariquindá and Mamucabas Rivers estuaries, Northeast Brazil.

\begin{tabular}{|c|c|c|}
\hline \multirow{2}{*}{ Seasons } & \multicolumn{2}{|c|}{ Number of ovigerous females } \\
\hline & Ariquindá River & Mamucabas River \\
\hline Autumn & 10 & 7 \\
\hline Winter & 0 & 0 \\
\hline Spring & 0 & 0 \\
\hline Summer & 23 & 28 \\
\hline
\end{tabular}

\section{DISCUSSION}

In the present study, sexual dimorphism in relation to size and weight was detected, with males showing larger carapace width (CW) and humid weight (HW) than females. Such phenomenon is commonly observed in brachyuran crabs (WARNER, 1967; DíAZ \& CONDE, 1989; ARAúso et al., 2012) and registered by several authors for U. cordatus (Alcântara-Filho, 1978; Ivo et al., 1999; VASCONCELos et al., 1999). According to Ivo et al. (1999), in $U$. cordatus the sexual dimorphism is related to the reproductive function, standing out the larger size and weight of the chelipods of males due to the role they develop during mating, entwining the female. Warner (1967) and Díaz \& Conde (1989) cite that this sexual dimorphism in size may be related to differential growth rates between the sexes, which were observed herein. Sexual differences in feeding rates, behavior and migratory phenomenon are factors that may influence on these differential growth rates (GIESEL, 1972; Wolf et al., 1975; Montague, 1980). Bliss (1968) emphasizes that the presence of the androgen gland in males is responsible for the weight gain right after maturity, influencing the sexual dimorphism. Since the feeding preferences and consumption rates of males and females are similar (NordHaus et al., 2006), we believe that the main factor acting in the sexual dimorphism of this population is the fact that the females invest more 
energy in reproduction than in growth (HARTNOLL, 1985; DIELE \& KoCH, 2010b), once the oocytes are cells greater than the spermatozoids. However, AraúJo \& CAlado (2008), studying an impacted mangrove at Northeast Brazil, found no difference in size and weight between sexes in a population of $U$. cordatus at the area, probably as a result of the selective capture of males.

In both sexes and estuaries, the CW vs. HW relationship showed a significant positive relation, with high values of $\mathrm{r}^{2}$, as also observed by PINHEIRO \& Fiscarelli (2009). Ucides cordatus showed negative allometric growth tending to isometry in this relationship. Similar results were also observed by Ivo et al. (1999) and ARAúJo \& CALADO (2008). These findings reflect the fact that, during its ontogeny, the crab grows more in width than in weight. Such fact may be related to the dilatation that this species develops in the lateral of the carapace, which stores six pairs of gills (PINHEIRO $\&$ FisCARelli, 2009). That dilatation, very expressive in the adult phase, allows a greater storage of atmospheric air, giving the species a better resistance to dehydration and allowing it to spend more time out of the water than aquatic brachyuran species (SANTOS et al., 1986). The development of the gills chamber is also found in other semiterrestrial species, as Cardisoma guanhumi (Latreille, 1825) (Gecarcinidae), which makes the $U$. cordatus very similar to other semiterrestrial crabs (SANTOS et al., 1985).

The values of $b$, which represents the weight increase, were within the established limit for aquatic organisms, which varies from two to four (LE CREN, 1951; Hartnoll, 1982). Such a result was observed in the swimming crabs Callinectes ornatus Ordway, 1863 (Branco \& Fracasso, 2004; Baptista-Metri et al., 2005) and C. danae Smith, 1869 (Branco et al., 1992; BAPTISTA-METRI et al., 2005), in the freshwater crab Dilocarcinus pagei Stimpson, 1861 (PINHEIRo \& TADDEI, 2005), and in the semiterrestrial crabs Armases angustipes (Dana, 1852) (KowalczuK \& Masunari, 2000) and U. cordatus (Pinheiro \& Fiscarelli, 2009; GoEs et al., 2010). That allows inferring that this rule may be extended to semiterrestrial crabs. Besides, such amplitude gives indicatives of changes in weight of the animal between different phases of growth and in the onset of sexual maturity (Mantelatto \& Fransozo, 1992; Pinheiro \& Fransozo, 1993).

The rates of growth were different according to the sex, being significantly higher in males. Such differences are related to the larger size and weight attained by males, as discussed before, and by the growth of their chelipods that, according to PINHEIRO \& HATTORI (2006), show a positive allometric pattern from the puberty molt towards.

In brachyuran species, generally the condition factor (CF) is higher in females, as observed in Dilocarcinus pagei (PINHeIRo \& TADDEI, 2005) and in $U$. cordatus (Pinheiro \& Fiscarelli, 2009), due to the larger size and weight attained by the ovaries after maturity. This may explain the higher CF of females at Mamucabas River. However, at Ariquindá River, there was no significant difference between the sexes, probably because other biological factors, as metabolism, nutritional aspects, stage of sexual maturity, time of recruitment, or a combination of them (RODRÍGUEZ, 1987), may be influencing the values of the CF, besides the gonads. The absence of sexual dimorphism in the CF was also observed in Arenaeus cribrarius (Lamarck, 1818) by Pinheiro \& Fransozo (1993). Spatial differences may occur even at a local scale, since place may influence the rates of growth of brachyuran species (BAPTISTA-METRI et al., 2005).

Many studies have related a decrease of the condition factor during the reproductive season (Vazzoler, 1996; Pinheiro \& Taddei, 2005; Pinheiro \& FisCARELli, 2009), as a result of the spawning. However, in the present study, no correlation was found between the $\mathrm{CF}$ and the abundance of ovigerous females. In general, lower $\mathrm{CF}$ is associated with the spawning period (Agostinho et al., 1990; Dutil et al., 2003; PinHeIRO \& TADDEI, 2005), but in the present the lowest value of the CF was observed in the winter, a season where no ovigerous females were recorded. Probably, some animals were captured when the energy stored in the hepatopancreas was reverted to the maturity of the gonads or to their reorganization after spawning, phenomena that lead to an increase of the $\mathrm{CF}$, while others were collected during spawning itself, which leads to a reduction of the CF. Thus, no clear pattern could be distinguished. Besides the reproductive period, it's well known that the molt leads to low condition factors (PINHEIRo \& TADDEI, 2005), and possibly the molting cycle is influencing in the present population. This assumption can be confirmed by the literature: according to Pinheiro \& Fiscarelli (2009), the low $\mathrm{CF}$ of $U$. cordatus observed in the winter is related to the fact that this period precedes the months with the highest frequency of ecdysis. Such result suggests that the condition factor by itself cannot be used as a single parameter for the determination of the reproductive period, but it has to be used in association with the monthly frequency in which ovigerous females are found during an annual range, and the data obtained from the macroscopic observation of the gonads and the observation of the copula (Pillay \& ONO, 1978; ChOY, 1988; Sumpton, 1990). Besides, the gonadosomatic index may be used for this purpose, since it also considers the weight of the ovaries (VAZZOLER, 1996).

The low abundance of ovigerous females is commonly observed in brachyuran species, as $C$. ornatus (Mantelatto \& Fransozo, 1997), Ocypode quadrata (Fabricius, 1787) (Negreiros-Fransozo et al., 2002), Goniopsis cruentata (Latreille, 1803) (Silva \& Oshiro, 2002; Сово \& Fransozo, 2003), Armases rubripes (Rathbun, 1897) (Lima et al., 2006), Uca rapax (Smith, 
1870) (CASTIGLIONi et al., 2007), Uca uruguayensis (Nobili, 1901) and Neohelice granulata (Dana, 1851) (CÉsAR et al., 2007), as well as $U$. cordatus (ARAúJo \& CAlado, 2008; present study). Probably these females may have a cryptic habit when compared to the nonovigerous females.

Some papers have reported on populations of $U$. cordatus under fisheries overexploitation, resulting in the diminution of the carapace width of the population (Botelho et al., 1999; Amaral \& Jablonski, 2005). ARAúJo \& CALADO (2008) related that the deforestation of the mangrove, as well as the industrial and domestic sewage that spills onto the Mundaú/Manguaba Estuarine Lagoon Complex (CELMM, state of Alagoas) also affect negatively the local population of $U$. cordatus. In the present study both populations of this species showed similar values of size and weight. This could suggest that the population of $U$. cordatus at Mamucabas River isn't suffering with the impacts that this estuary is currently receiving, being adapted to the habitat. However, the $\mathrm{CF}$ of both males and females differed between estuaries, being lower at Mamucabas River. Some environmental impacts cannot be detected just taking into account the external aspects of a given organism. A deviation from the normal status is more likely to be detected with the use of bioindicators, including bioindicators at individual level, as the condition factor (ARIAS et al., 2007). Considering the body morphology, specimens with the same size can apparently demonstrate the same healthiness, but internally, their physiology may be affected, which can be detected through a diminution of the $\mathrm{CF}$. The mangrove in Mamucabas has been reduced by the housing occupation, deposition of waste and deforestation (SANTOS et al., 2001), with many trees had been cut. This may reduce the food resource for this herbivorous crab, and these lower rates of feeding probably may reduce the CF.

The evaluation of the sexual variations of the $\mathrm{CW}$ vs. HW relationship and the condition factor proved to be good parameters for the study of the biology of $U$. cordatus, especially regarding the sexual dimorphism of the growth, as well as evidencing the environmental impacts. Indeed, more studies are needed on the growth and condition factor for this species, as well as for other freshwater, estuarine and marine Brachyura with socioeconomic importance. The data obtained in these studies are important for management plans, since they allow monitoring and evidencing environmental impacts, as observed herein.

Acknowledgements. The authors are grateful to the Fundação de Amparo à Ciência e Tecnologia do Estado de Pernambuco (FACEPE), for financial support for fieldwork to D.S.C (APQ: 01082.04/07), to CNPq for a fellowship to D.S.C. and to CAPES for a fellowship to M.S.L.C.A. We are grateful to Adriano Martins for his help during fieldwork. All sampling in this study was conducted in compliance with current applicable state and federal laws (ICMBio 14340-1).

\section{REFERENCES}

Agostinho, A. A.; Barbieri, G.; Verano, J. R. \& Hahn, N. S. 1990. Variação do fator de condição e do índice hepatossomático e suas relações com o ciclo reprodutivo em Rhinelepis aspera (Agassis, 1829) (Osteichthyes, Loricariidae) no rio Paranapanema, Porecatu, PR. Ciência e Cultura 42:711-714.

Alcântara-Filho, P. 1978. Contribuição ao estudo da biologia e ecologia do caranguejo-uçá Ucides cordatus cordatus (Linnaeus, 1763) (Decapoda, Brachyura) no manguezal do Rio Ceará (Brasil). Arquivos de Ciências do Mar 18:1-41.

AmARAL, A. C. Z. \& JABLONSKI, S. 2005. Conservação da biodiversidade marinha e costeira no Brasil. Megadiversidade 1:43-51.

Araújo, M. S. L. C \& Calado, T. C. S. 2008. Bioecologia do caranguejo-Uçá Ucides cordatus (Linnaeus) no Complexo Estuarino Lagunar Mundaú/Manguaba (CELMM), Alagoas, Brasil. Revista da Gestão Costeira Integrada 8:169-181.

Araújo, M. S. L. C.; Barreto, A. V.; Negromonte, A. O. \& Schwamborn, R. 2012. Population ecology of the blue crab Callinectes danae (Crustacea: Portunidae) in a Brazilian tropical estuary. Anais da Academia Brasileira de Ciências 84(1):129-138.

Arias, A. R. L.; Buss, D. F.; Alburquerque, C.; Inácio, A. F.; Freire, M. M.; Egler, M.; MugnaI, R. \& Baptista, D. F. 2007. Utilização de bioindicadores na avaliação de impacto e no monitoramento da contaminação de rios e córregos por agrotóxicos. Ciência e saúde coletiva 12:61-72.

Ayres, M.; Ayres Jr, M.; Ayres, D. L. \& Santos, A. A. S. 2007. Bioestat - Aplicações estatísticas nas áreas da ciências biomédicas. Belém, Sociedade Civil Mamirauá. 324p.

Baptista-Metri, C.; Pinheiro, M. A. A.; Blankensteyn, A. \& Borzone, C. A. 2005. Biologia populacional e reprodutiva de Callinectes danae Smith (Crustacea: Portunidae), no Balneário Shangri-lá, Pontal do Paraná (PR), Brasil. Revista Brasileira de Zoologia 22:446-453.

BLiss, D.E. 1968. Transition from Water to Land in Decapod Crustaceans. American Zoologist 8:355-392.

Botelho, E. R. O.; Dias, A. F. \& Ivo, C. T. C. 1999. Estudo sobre a biologia do caranguejo uçá Ucides cordatus cordatus (Linnaeus, 1763) capturado nos Estuários dos Rios Formoso (Rio Formoso) e Ilhetas (Tamandaré), no Estado de Pernambuco. Boletim Técnico Científico do CEPENE 7:117-145.

Braga, F. M. S.; Braga, M. A. S. \& Goitein, R. 1985. Fator de condição e alimentação de Paralonchurus brasiliensis (Osteichthyes, Sciaenidae) na região da ilha Anchieta (lat. 233's - long. $\left.45^{\circ} 05^{\prime} \mathrm{W}\right)$, Ubatuba, Estado de São Paulo. Naturalia 10:1-11.

Branco, J. O. \& Fracasso, H. A. A. 2004. Biologia populacional de Callinectes ornatus (Ordway) na Armação do Itapocoroy, Penha, Santa Catarina, Brasil. Revista Brasileira de Zoologia 21:91-96.

Branco, J. O.; Lunardón, M. J.; Avila, M. G. \& Miguel, C. F. 1992. Interação entre fator de condição e índice gonadossomático como indicadores do período de desova em Callinectes danae Smith (Crustacea, Portunidae) da Lagoa da Conceição, Florianópolis, Santa Catarina, Brasil. Revista Brasileira de Zoologia 9:175-180.

Castiglioni, D. S. \& Coelho, P. A. 2011. Determinação da maturidade sexual de Ucides cordatus (Crustacea, Brachyura, Ucididae) em duas áreas de manguezal do litoral sul de Pernambuco, Brasil. Iheringia, Série Zoologia 101(1-2):138-144.

Castiglioni, D. S.; Negreiros-Fransozo, M. L. \& Cardoso, C. F. 2007. Breeding season and molt cycle of the fiddler crab Uca rapax (Brachyura: Ocypodidae) in a subtropical estuary, Brazil, South America. Gulf and Caribbean Research 19:11-20.

Castiglioni D. S.; Negreiros-Fransozo, M. L. \& Mortari, R. C. 2006. Biologia populacional do caranguejo violinista Uca rapax (Smith, 1870) (Crustacea, Ocypodoidea) proveniente de uma área de manguezal degradado em Paraty, RJ, Brasil. Atlântica 28:73-86.

Castiglioni, D. S.; Silva, J. V. C. L. \& Azevedo, D. S. 2011. Relative growth and its use to determine the morphological sexual maturity of Ucides cordatus (Linnaeus, 1763) (Decapoda, Brachyura, Ucididae) from two mangrove areas on the Northeastern Brazilian coast. Crustaceana 84:1221-1241.

César, I. I.; Armendariz, L. C. \& Becerra, R. V. 2007. Fecundity of Uca uruguayensis and Chasmagnathus granulatus (Decapoda, Brachyura) from the "Refúgio de Vida Silvestre", Bahía Samborombón, Argentina. Brazilian Journal of Biology 67:749753. 
Chоу, S. C. 1988. Reproductive biology of Liocarcinus puber and Liocarcinus holsatus (Decapoda, Brachyura, Portunidae) from the Gower Peninsula, South Wales. Marine Ecology 9:227-241.

Christofoletti, R. A.; Hattori, G. Y. \& Pinheiro, M. A. A. 2012. Food selection by a mangrove crab: temporal changes in fasted animals. Hydrobiologia 1-10 (online first).

CoBo, V. J. \& Fransozo, A. 2003. External factors determining breeding season in the red mangrove crab Goniopsis cruentata (Latreille) (Crustacea: Brachyura: Grapsidae) on the São Paulo state northern coast, Brazil. Revista Brasileira de Zoologia 20:213-217.

CPRH (Companhia Pernambucana do Meio Ambiente). 1999. Diagnóstico sócio-ambiental e ZEEC - Zoneamento Ecológico Econômico Costeiro Litoral sul de Pernambuco. Recife, CPRH/GERCO. 91p.

2003. Diagnóstico Sócio-Ambiental do litoral sul de Pernambuco. Recife, CPRH/GERCO. 87p.

Dalabona, G. \& Loyola e Silva, J. 2005. Período reprodutivo de Ucides cordatus (Linnaeus, 1763) (Brachyura, Ocypodidae) na Baía de Laranjeiras. Acta Biologica 34:115-126.

Díaz, H. \& Conde, J. E. 1989. Population dynamics and life of mangrove crab Aratus pisonii (Brachyura, Grapsidae) in a marine environment. Bulletin of Marine Science 45:148-163.

Diele, K. \& Koсн, V. 2010a. Comparative population dynamics and life history strategies of mangrove crabs, genera $U c a$ and Ucides. In: Saint-Paul, U. \& Schneider, H. eds. Mangrove dynamics and management in north Brazil. Ecological Studies. BerlinHeidelberg, Springer. v. 211, p. 275-285.

2010b. Growth and mortality of the exploited mangrove crab Ucides cordatus (Ucididae) in N-Brazil. Journal of Experimental Marine Biology and Ecology 395:171-180.

Diele, K.; Koch, V. \& Saint-Paul, U. 2005. Population structure, catch composition and CPUE of the artisanally harvested mangrove crab Ucides cordatus (Ocypodidae) in the Caeté estuary, North Brazil: Indications for overfishing? Aquatic Living Resource 18:169-178.

Dutil, J. D.; Lambert, Y. \& Denis, C. 2003. Winter and spring changes in condition factor and energy reserves of wild cod compared with changes observed during food-deprivation in the laboratory. ICES Journal of Marine Science 60:780-786.

Froese, R. 2006. Cube law, condition factor, and weight-length relationships: history, meta-analysis and recommendations. Journal of Applied Ichthyology 22:241-253.

Geraldes, M. G. \& Calventi, I. B. 1983. Estudios experimentales para el mantenimiento en cautiverio del cangrejo Ucides cordatus. Ciencia Interamericana 23:41-53.

Giesel, J. T. 1972. Sex ratio, rate of evolution, and environmental heterogeneity. American Naturalist 106:380-387.

Goes, P.; Branco, J. O.; Pinheiro, M. A. A.; Barbieri, E; Costa, D. \& Fernandes, L. L. 2010. Bioecology of the uçá-crab, Ucides cordatus (Linnaeus, 1763), in Vitória Bay, Espírito Santo State, Brazil. Brazilian Journal of Oceanography 58(2):153-163.

Grego, C. K. S.; Feitosa, F. A. N.; Silva, M. H.; Cunha, M. G. G. S. \& Nascimento-Filho, G. A. 2009. Fitoplâncton do ecossistema estuarino do Rio Ariquindá (Tamandaré, Pernambuco, Brasil): variáveis ambientais, biomassa e produtividade primária. Atlântica 31:183-198.

Hartnoll, R. G. 1982. Growth. In: Bliss, D. E. ed. The biology of Crustacea: embryology, morphology and genetic. New York, Academic Press. p. 111-196.

1985. Growth, sexual maturity and reproductive output. In: Wenner, A. M. ed. Factors in adult growth. Rotterdam, A. A. Balkema. p. 101-123.

Hattori, G. Y. \& Pinheiro, M. A. A. 2003. Fertilidade do caranguejo de mangue Ucides cordatus (Linnaeus) (Crustacea, Brachyura, Ocypodidae), em Iguape (São Paulo, Brasil). Revista Brasileira de Zoologia 20(2):309-313.

Huxley, J. S. 1950. Relative growth and form transformation. Proceedings of the Zoological Society of London 137:465-469.

Ivo, C. T. C. \& Gesteira, T. C. V. 1999. Sinopse das observações do Caranguejo uçá, Ucides cordatus cordatus (Linnaeus, 1763) capturado em estuários de sua ocorrência no Brasil. Boletim Técnico Científico do CEPENE 7:9-51.

Ivo, C. T. C.; Dias, A. F. \& Mota, R. I. 1999. Estudo sobre a biologia do caranguejo uçá Ucides cordatus cordatus (Linnaeus, 1763) capturado no Delta do Parnaíba, Estado do Piauí. Boletim Técnico-Científico do CEPENE 7(1):53-84.
Kowalczuk, V. G. L. \& Masunari, S. 2000. Crescimento relativo e determinação da idade na fase juvenil de Armases angustipes (Dana) (Decapoda, Brachyura, Grapsidae). Revista Brasileira de Zoologia 17:17-24.

Le Cren, E. D. 1951. The lenght-weight relationship and seasonal cycle in gonad weight and condition factor in the perch (Perca fluviatilis). Journal of Animal Ecology 20:201-219.

Lima, G. V.; Soares, M. R. S. \& Oshiro, L. M. Y. 2006. Reproductive biology of the sesarmid crab Armases rubripes (Decapoda: Brachyura) from an estuarine area of the Sahy river, Sepetiba Bay, Rio de Janeiro, Brazil. Iheringia, Série Zoologia 96:47-52.

Lotrich, V. A. 1973. Growth, production, and community composition of fishes inhabiting a first-second, and third-order stream of eastern Kentucky. Ecological Monographs 43(3):377-397.

Macintosh, D. J. 1988. The ecology and physiology of decapods of mangrove swamps. Symposia of the Zoological Society of London 59:315-341.

Mantelatto, F. L. M. \& Fransozo, A. 1992. Relação peso/largura da carapaça no caranguejo Hepatus pudibundus (Herbst, 1785) (Crustacea, Decapoda, Calappidae) na região de Ubatuba, SP, Brasil. Arquivos de Biologia e Tecnologia 35(4):719-724.

. 1997. Fecundity of the crab Callinectes ornatus Ordway, 1863 (Decapoda, Brachyura, Portunidae) from the Ubatuba region, São Paulo, Brazil. Crustaceana 70(2):214-226.

MMA (Ministério do MeIo AmBiente). 2004. Instrução Normativa $n^{0}$ 5, Anexo II: Lista Nacional das espécies de invertebrados aquáticos e peixes sobrexplotadas ou ameaçadas de sobrexplotação. Disponível em: <http://www4.icmbio.gov.br/ cepsul/legislacao.php?id_arq=267>. Acesso em: 16.01.2012.

Montague, C. L. 1980. A natural history of temperate western Atlantic fiddler crabs. Contributions in Marine Science 23:25-55.

Moura, R. T. \& Passavante, J. Z. O. 1995. Biomassa fitoplanctônica na baía de Tamandaré, Rio Formoso - Pernambuco, Brasil. Trabalhos Oceanográficos da Universidade Federal de Pernambuco 23:1-15.

Mota-Alves, M. I. 1975. Sobre a reprodução do caranguejo-uçá, Ucides cordatus (Linnaeus), em mangues do Estado do Ceará (Brasil). Arquivos de Ciências do Mar 15(2):85-91.

Negreiros-Fransozo, M. L.; Fransozo, A. \& Bertini, G. 2002. Reproductive cycle and recruitment period of Ocypode quadrata (Decapoda: Ocypodidae) at a Sandy beach in southeastern Brazil. Journal of Crustacean Biology 22:157-161.

Nordhaus, I.; Diele, K. \& WolfF, M. 2009. Activity patterns, feeding and burrowing behaviour of the crab Ucides cordatus (Ucididae) in a high intertidal mangrove forest in North Brazil. Journal of Experimental Marine Biology and Ecology 374:104-112.

Nordhaus, I.; WolfF, M. \& Diele, K. 2006. Litter processing and population food intake of the mangrove crab Ucides cordatus in a high intertidal forest in northern Brazil. Estuarine, Coastal and Shelf Science 67:239-250.

Nordi, N.; Nishida, A. K. \& Alves, R. R. N. 2009. Effectiveness of two gathering techniques for Ucides cordatus in Northeast Brazil: implications for the sustainability of mangrove ecosystems. Human Ecology 37:121-127.

Ostrensky, A.; Sternhain, U. S.; Brun, E.; Wegbecher, F. X. \& Pestana, D. 1995. Análise da viabilidade técnico-econômica dos cultivos do caranguejo-uçá Ucides cordatus (Linnaeus, 1763) no litoral paranaense. Arquivos de Biologia e Tecnologia 38(3):939-947.

Pillay, K. K. \& Ono, Y. 1978. The breeding cycles of two species of grapsidae crabs (Crustacea, Decapoda) from the north coast of Kyushu, Japan. Marine Biology 45:237-248.

Pinheiro, M. A. A. \& Fiscarelli, A. G. 2001. Manual de apoio à fiscalização do caranguejo-uçá (Ucides cordatus). Florianópolis, UNESP/IBAMA/CEPSUL. 43p.

2009. Length-weight relationship and condition factor of the mangrove crab Ucides cordatus (Linnaeus, 1763) (Crustacea, Brachyura, Ucididae). Brazilian Archives of Biology and Technology 52:397-406.

Pinheiro, M. A. A. \& Fransozo, A. 1993. Relative growth of the speckled swimming crab Arenaeus cribrarius (Lamarck, 1818) (Brachyura, Portunidae), near Ubatuba, State of São Paulo, Brazil. Crustaceana 65:365-376.

Pinheiro, M. A. A. \& Hattori, G. Y. 2006. Relative growth of the mangrove crab Ucides cordatus (Linnaeus, 1763) (Crustacea, Brachyura, Ocypodidae) at Iguape, São Paulo, Brazil. Brazilian Archives of Biology and Technology 49:813-823. 
Pinheiro, M. A. A. \& Taddei, F. G. 2005. Relação peso/largura da carapaça e fator de condição em Dilocarcinus pagei Stimpson (Crustacea, Trichodactylidae), em São José do Rio Preto, São Paulo, Brasil. Revista Brasileira de Zoologia 22:825-829.

Rodríguez, A. 1987. Biologia del langostino Penaeus kerathurus (Forskal, 1775) del golfo de Cádiz. III. Biometría, edad y crecimiento. Investigaciones Pesqueras 51:23-38.

Santos, M. C. F.; Botelho, E. R. O. \& Ivo, C. T. C. 2001. Biologia populacional e manejo da pesca de aratu, Goniopsis cruentata (Latreille, 1803) (Crustacea: Decapoda: Grapsidae) no litoral sul de Pernambuco-Brasil. Boletim Técnico Científico do CEPENE 9:87-123.

Santos, M. C. F.; Engelftein, M. \& Gabrielli, M. A. 1985. Relationships concerning respiratory devices in crabs from different habitats. Compared Biochemestry and Physiology 81(3):567-570

Santos, M. C. F.; Suadicani, S. O.; Martinez, C. B. R. \& Lobo, E. S. 1986. Rates of water loss in four crabs from different habitats. Comparative Biochemestry and Physiology Part A: Physiology 85:309-312.
Silva, Z. S. \& Oshiro, L. M. Y. 2002. Aspectos reprodutivos de Goniopsis cruentata (Latreille) (Crustacea, Brachyura, Grapsidae) na Baía de Sepetiba, Rio de Janeiro, Brasil. Revista Brasileira de Zoologia 19:907-914.

Sumpton, W. D. 1990. Morphometric growth and fisheries biology of the crab Charybdis natator (Herbst) in Moreton Bay, Australia (Decapoda, Brachyura). Crustaceana 59:113-120.

Vasconcelos, E. M. S.; Vasconcelos, J. A. \& Ivo, C. T. C. 1999. Estudo sobre a biologia do caranguejo uçá Ucides cordatus cordatus (Linnaeus, 1763) capturado no Estuário do Rio Curimatau (Canguaretama) no Estado do Rio Grande do Norte. Boletim Técnico Científico do CEPENE 7:85-116.

VAzzoler, A. E. A. M. 1996. Biologia da reprodução de peixes teleósteos: teoria e prática. Maringá, Nupelia. 169p.

WARner, G. F. 1967. The life history of the mangrove tree crab, Aratus pisonii. Journal of Zoology 153:321-335.

Wolf, P.; Shanholtaer, S. F. \& Reimold, R. J. 1975. Population estimates for Uca pugnax on Duplin estuary marsh. Georgia, USA. Crustaceana 29:79-91.

ZAR J. H. 1996. Biostatistical analysis. Upper Saddle River, PrenticeHall. 662p. 